\title{
Determining Appropriate Broad Bed and Furrow Length for Durum Wheat Production Under Different Land Slopes of Vertisols in the Central Ethiopian Highlands
}

ISSN: 2637-7659

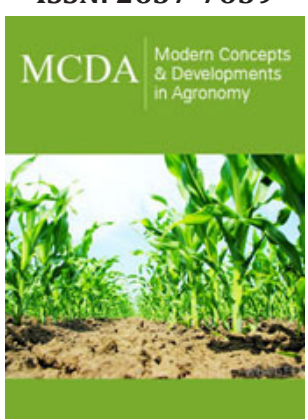

*Corresponding author: Saba Fetene, Ethiopian Institute of Agricultural Research (EIAR), Addis Ababa, Ethiopia

Submission: 慧April 12, 2021

Published: 战April 29, 2021

Volume 8 - Issue 3

How to cite this article: Saba Fetene, Assefa Gonfa, Sosena Amsalu. Determining Appropriate Broad Bed and Furrow Length for Durum Wheat Production Under Different Land Slopes of Vertisols in the Central Ethiopian Highlands. Mod Concep Dev Agrono. 8(3). MCDA. 000690. 2021. DOI: 10.31031/MCDA.2021.08.000690

Copyright@ Saba Fetene. This article is distributed under the terms of the Creative Commons Attribution 4.0 International License, which permits unrestricted use and redistribution provided that the original author and source are credited.

\author{
Saba Fetene ${ }^{1 *}$, Assefa Gonfa ${ }^{1,2}$ and Sosena Amsalu ${ }^{1,2}$ \\ ${ }^{1}$ Ethiopian Institute of Agricultural Research (EIAR), Addis Ababa, Ethiopia \\ ${ }^{2}$ Debre Zeit Agricultural Research Center (DZARC), Bishoftu, Ethiopia
}

\begin{abstract}
Vertisols are prone to waterlogging when they are flat and to erosion when they are sloppy due to their higher clay content. Hence, to avoid soil and water loss, while using the Broad Bed and Furrow (BBF), slope and BBF length have to be considered. Field experiments were conducted on Vertisols having different slopes $(1,2$ and $3 \%)$ and BBF lengths $(10,20$ and $30 \mathrm{~m})$ using split-plot design. Slope gradients and BBF lengths were the main and sub-plot treatments, respectively. Results revealed the main and interaction effect of BBF lengths and slope gradients were significant on all parameters, except for tiller's number. Higher grain yield (5757kg ha-1), was obtained from plots of $10 \mathrm{~m}$ BBF length for $2 \%$ slope, while higher grain yield of 2148 and $3318 \mathrm{~kg}$ ha- 1 recorded from $20 \mathrm{~m}$ of BBF for both $1 \%$ and $3 \%$ slopes, respectively. However, slope gradient and BBF lengths did not brought a significant effect on soil erosion and deposition. This could be due the slopes selected are under the same slope category. Therefore, further study is needed to estimate effects of BBF lengths and slopes on soil loss and crop yield using lands having large slope gradient or categories.
\end{abstract}

Keywords: Slope; BBF length; Erosion; Deposition; Wheat; Yield

\section{Introduction}

In Ethiopia, Veritisols cover $15-20 \%$ of the highland's areas. As they contain high proportion of swelling clay such as smectites, they are highly prone to water erosion. In fact, when clay particles are swollen, infiltration becomes negligible, so surface runoff increases [1]. Sheet and gully erosion are observed more in Vertisols [2]. The loss of soil on the land surface by wind and water erosion has been identified as a major constraint in generating enough food to feed the world's escalating population [1]. Soil erosion by water increases when water at the soil surface exceeds water infiltration [3]. The author further mentioned that good cohesiveness between soil particles and soil cemented by organic matter may resist water and wind erosion. [4] reported that land degradation reduces food production by 15 to $30 \%$. Erosion is a serious problem under present management, especially on fallow cultivated during the rainy season and on some sloping land in the highlands. [5] also indicated that the highlands of Ethiopia, where more than $95 \%$ of food is grown, has been losing its soils at an alarming rate. Vertisols in these areas are naturally fertile, but present difficult challenges for farmers for crop production because of susceptibility of soil erosion and other physical constraints. Further, erosion affects the infiltration rate, organic matter content, aggregate stability, bulk density and porosity of soil [6].

Draining the excess water in Vertisols to improve crop production is important but application of the Broad Beds and Furrows (BBF) is limited to areas having slope of more than $2 \%$ as it requires a slope steep enough for drainage while avoiding erosion [2]. The BBF is designed in such a way that the raised based portion acts as an in situ 'bund' to ensure the soil stability and the shallow furrow $(15 \mathrm{~cm}$ deep) provides surface drainage to promote aeration and prevent waterlogging of crops grown on the bed [7]. However, to avoid soil and water loss in Vertisols while using the BBF system the slope and length of the beds have to be considered which could allow runoff to occur at non-erosive velocities and help maintain optimum moisture supply in the effective root zone. Therefore, this activity was conducted to 
recommend the best land slope and Broad bed furrow combinations for better soil conservation, efficient water drainage and yield of wheat.

\section{Material and Methods}

\section{Description of the experimental area}

This experiment was conducted for two consecutive cropping seasons, from 2015 to 2016, on Vertisols of Minjar-Shenkora district at Memihir hager kebele, on farmers' fields. The study area is geographically located at $8^{\circ} 46^{\prime} 33.5^{\prime \prime} \mathrm{N}$ and $39^{\circ} 16^{\prime} 40.7^{\prime \prime} \mathrm{E}$ at an altitude of 2257 m.a.s.l. The mean annual rainfall received by area was 612 and 635mm in 2015 and 2016, respectively (Figure 1).

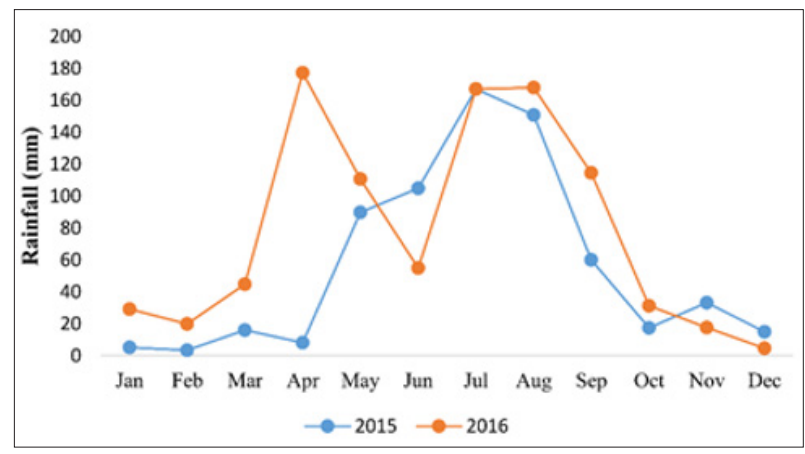

Figure 1: Mean monthly rainfall in 2015 and 2016 cropping seasons at Minjar-Shenkora district.

The soil type is Vertisols with a clayey soil texture, which is known for its good soil fertility and water-logging problems [8]. The study had a neutral soil $\mathrm{pH}$ with a bulk density and organic matter content of $196 \mathrm{~g} \mathrm{~kg}^{-1}$ and $1.23 \mathrm{~g} \mathrm{~cm}^{-3}$, respectively.

\section{Experimental set-up and procedure}

Farmlands of three different slopes were purposely selected to recommend the best land slope and Broad Beds and Furrows (BBF) combinations for better soil conservation and efficient water drainage. The selected slopes were 1, 2 and $3 \%$ and three different furrow lengths $(10 \mathrm{~m}, 20 \mathrm{~m}$ and $30 \mathrm{~m})$ were used. The experiment was laid out using split plot design with three replications. The slope differences were used as main plots and the BBF lengths as sub plots. Water was drained safely without interfering with other experimental plots using the recommended BBF, which have 80 and $20 \mathrm{~cm}$ of bed and furrow width. The test crop was Durum-wheat where Ude variety was used. All plots received similar cultural practices. To examine effects of different BBF lengths and slopes on the test crop, data of plant height, number of tillers, grain yield and straw yield including soil erosion and deposition.

\section{Estimation of soil loss}

The soil status had been monitored and collected using Erosion pins (pin method) at one-month interval. This method is a widely used method, which consists of driving a pin in to the soil so that the top of the pin gives a datum from which changes in the soil surface level can be measured [9]. A $0.5 \mathrm{~m}$ pin with $0.8 \mathrm{~cm}$ diameter was used as a pin. The pins were spaced at 5 meters per plot. This makes it three pins on a plot with length of 10 meter, four pins on a plot with length of 20 meters plot and six pins on a plot with length of 30 meters plot. The pins were buried $10 \mathrm{~cm}$ below the ground to the level of the mark on the pin. The pins were installed throughout the study period. Every month the distance of the pin the height of soil loss by erosion (h), corresponding to the distance between the pin mark and the current surface of the soil was measured with a small graduated ruler. The amount of soil loss was quantified using the following formula:

$$
S=h * B D * A
$$

Where S- is the amount of soil loss by erosion,

BD- is the bulk density $\left(\mathrm{g} / \mathrm{cm}^{2}\right)$,

h- is the height of soil loss and

A- is the gap area $\left(\mathrm{cm}^{2}\right)$

The amount of soil deposition was calculated by multiplying change of pin length by bulk density of soil layer $\left(\mathrm{kg} \mathrm{m}^{-2}\right)$.

\section{Statistical analysis}

The collected soil erosion, deposition and agronomic data were subjected to combined analysis of variance (ANOVA) over years using the General Linear Model Procedure (Proc GLM) of SAS statistical package. The means were separated using the Least Significant Difference (LSD) test at $5 \%$ level of significance.

\section{Result and Discussion}

\section{Soil erosion and deposition}

The combined results showed that BBF lengths and the slope gradients had no significant effect on soil erosion and deposition (Figure 2). Even though there was no statistical difference, an increasing trend of soil erosion and deposition observed as the slope increases. Soil Erosion (SE) has increased from 0.065 to 173, 0.082 to 0.130 and 0.130 to $0.351 \mathrm{t} /$ ha of soil for 10,20 and $30 \mathrm{~m}$ length of BBF, respectively across the slope gradient (Figure 2). SDMF also showed an increasing trend from 0.143 to $0.173,0.156$ to 0.303 and 0.130 to $0.286 \mathrm{t} / \mathrm{ha}$ of soil for 10,20 and $30 \mathrm{~m}$ length of $\mathrm{BBF}$, respectively with slope gradient.

Moreover, SDBF increased from 0.234 to $0.286,0.286$ to 0.325 and 0.325 to $0.351 \mathrm{t} /$ ha of soil for 10,20 and $30 \mathrm{~m}$ length of BBF, respectively across the slope gradient (Figure 2). Similarly, the study of [10] indicated an increment of soil erosion with increasing slope gradient in different land uses.

Regards to soil loss and deposition across slope length, an increment was recorded for SE, SDMF and SDBF from $10 \mathrm{~m}$ to $30 \mathrm{~m}$ slope length. For the experimental field of $1 \%$ slope, SE increased from 0.65 to 0.130 , SDBF increased from 0.234 to $0.325 t$ / ha of soil. Similarly, SE has increased from 0.125 to 0.126 , SDBF increased from 0.95 to 0.325 , while SDMF decreased from 0.173 to 0.139 t/ha of soil for the $2 \%$ slope. On the experimental field of $3 \%$ slope, SE increased from 0.117 to 0.130 , SDMF increased from 0.173 to 0.286 and SDBF increased from 0.286 to $0.351 \mathrm{t} /$ ha of soil along the slope 
length (Figure 2). This is an indication for soil loss at the upper slope positions and its accumulation at the foot slope positions.

Another research also showed that, in the range between 11 and $44 \mathrm{~m}$, the soil losses by erosion are related in a positive and linear manner with an increase in slope length [11]. Increments of soil erosion with the slope gradient could be a result of respective increase in velocity and volume of surface runoff. [12] reported a significant effect of slope on soil and runoff losses. On the other hand, SDMF has shown inconsistent results as BBF length increase and maximum results recorded for BBF length of $20 \mathrm{~m}$ across the slope, despite its smooth trend for all slopes as BBF length increases (Figure 2).

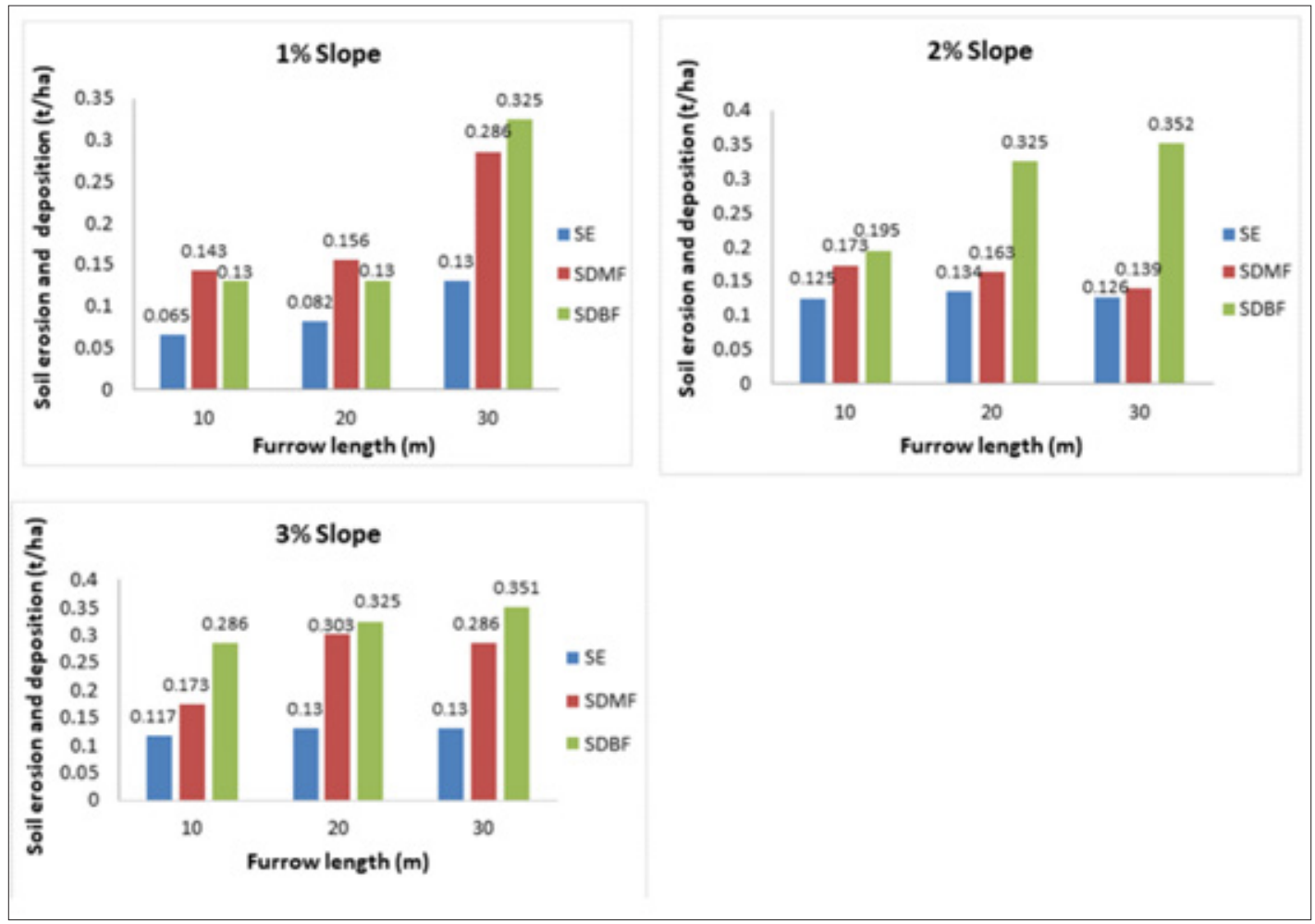

Figure 2: Effect of slope and BBF length on soil erosion and deposition.

In general, results of the present finding indicated that as the slope gradients and length of broad bed and furrow increases, there is a general tendency of increases in SDMF (Figure 2). In most cases, the SDBF in each slope class is higher than the SDMF. This is an indication of soil movement (due to erosion) from the upper field to the bottom of the field in the direction of water flow. Soil erosion supposedly increases in proportion to some power of slope length. Higher erosion on longer slopes may be due to increased runoff velocity on longer slope [13]. Thus, some soil eroded from the upper field is deposited at the lower end.

\section{Yield and yield components of wheat}

Analysis of variance over two years indicated that the main effect of year, slope and furrow and bed length had a significant $(\mathrm{P}<0.05)$ effect on most of the studied yield parameters of wheat. On the other hand, the interaction of slope and furrows and bed length had a significant $(\mathrm{P}<0.05)$ effect on grain yield, but not on other parameters.

The main effect of year had a significant $(\mathrm{P}<0.05)$ effect on grain and straw yield including plant height, but not number of tillers. The higher yield of grain and straw and also higher plant height was recorded in 2015 cropping season. This could be due to the higher rainfall amount and distribution during the critical wheat growth stages on June, July and August in year 2015 related to 2016 (Figure 1).

Table 1 Main effects of broad beds and furrows length and slope gradients on different yield components of wheat during 2015 and 2016 cropping seasons.

Analysis conducted for the main effects revealed the significant $(\mathrm{P}<0.05)$ effect of land slope on the yield and yield components of wheat except for number of tillers. Higher yield of grain $(4991 \mathrm{~kg}$ $\left.\mathrm{ha}^{-1}\right)$ and straw $\left(7749 \mathrm{~kg} \mathrm{ha}^{-1}\right)$ as well as plant height $(87.7 \mathrm{~cm})$ was obtained from plots having $2 \%$ slope. However, the lowest grain yield $\left(1765 \mathrm{~kg} \mathrm{ha}^{-1}\right)$ was recorded on the $1 \%$ slope field. Similarly, the lowest plant height and number of tillers was recorded from the plots having the same field (Table 1). This result is in the contrary of the results of [14] who reported that the yield of wheat declines as the slope gradient rises. The reason for lower wheat yield as the slope gradient increases might be yield of wheat on Vertisols are strongly associated with drainage. Drainage intern associated with slope gradient, and excess water drain slower on lower slopes of Vertisols. 
The main effects of BBF length have also affected significantly $(\mathrm{P}<0.05)$ grain and straw yield as well as plant height, but not number of tillers. Higher grain yield (3490 $\mathrm{kg} \mathrm{ha}^{-1}$ ) and plant height $(81.8 \mathrm{~cm})$ was recorded on plots having bed length of $20 \mathrm{~m}$. Whereas, the higher straw yield, $7366 \mathrm{~kg} \mathrm{ha}^{-1}$ and plant height, $82.0 \mathrm{~cm}$ was obtained from plots having $30 \mathrm{~m}$ BBF length (Table 1).

Table 1: Main effects of broad beds and furrows length and slope gradients on different yield components of wheat during 2015 and 2016 cropping seasons.

\begin{tabular}{|c|c|c|c|c|}
\hline Treatments & GY & SY & PH & NT \\
\hline \multicolumn{5}{|c|}{ Year } \\
\hline 2015 & $3944 \mathrm{a}$ & $7588 \mathrm{a}$ & $83.2 \mathrm{a}$ & $7.1 \mathrm{a}$ \\
\hline 2016 & $2599 \mathrm{~b}$ & $5791 \mathrm{~b}$ & $80.3 \mathrm{~b}$ & $7.7 \mathrm{a}$ \\
\hline LSD (P<0.05) & 366 & 816 & 1.9 & ns \\
\hline \multicolumn{5}{|c|}{ Slope } \\
\hline $1 \%$ & $1765 \mathrm{c}$ & $5359 \mathrm{~b}$ & $78.7 \mathrm{~b}$ & $7.6 \mathrm{a}$ \\
\hline $2 \%$ & $4991 \mathrm{a}$ & $7749 \mathrm{a}$ & $87.7 \mathrm{a}$ & $7.4 \mathrm{a}$ \\
\hline $3 \%$ & $3058 \mathrm{~b}$ & $6959 \mathrm{a}$ & $78.8 \mathrm{~b}$ & $7.3 \mathrm{a}$ \\
\hline LSD (P<0.05) & 449 & 1000 & 2.4 & ns \\
\hline \multicolumn{5}{|c|}{ BBF length } \\
\hline $10 \mathrm{~m}$ & $3392 \mathrm{a}$ & $6330 \mathrm{~b}$ & $81.3 \mathrm{a}$ & $7.4 \mathrm{a}$ \\
\hline $20 \mathrm{~m}$ & $3490 \mathrm{a}$ & $6373 \mathrm{ab}$ & $81.8 \mathrm{a}$ & $7.6 \mathrm{a}$ \\
\hline $30 \mathrm{~m}$ & $2932 \mathrm{~b}$ & $7366 \mathrm{a}$ & $82.0 \mathrm{a}$ & $7.3 \mathrm{a}$ \\
\hline LSD (P<0.05) & 449 & 1000 & ns & ns \\
\hline S x BBFL & $*$ & ns & ns & ns \\
\hline CV (\%) & 20.4 & 22.2 & 4.4 & 18.2 \\
\hline
\end{tabular}

* and NS means significant and non-significant at $\mathrm{P}<0.05$, respectively. $\mathrm{SY}=$ Straw yield, $\mathrm{BY}=$ Biomass yield, $\mathrm{PH}=\mathrm{Plant}$ height, NT=Number of tillers, $\mathrm{S}=$ Slope, BBFL=Broad beds and furrows length

Results further indicated that interaction of BBF length with slope brought a significant effect on grain yield of wheat $(\mathrm{P}<0.05)$. However, their interaction effect was non-significant on straw yield, plant height and number of tillers $(\mathrm{P}>0.05)$ (Table 2). Wheat grain yield, $5757 \mathrm{~kg} \mathrm{ha}^{-1}$, obtained from combination of $20 \mathrm{~m}$ length of BBF with $2 \%$ slope was found significantly superior over others. Whereas, combination of $10 \mathrm{~m}$ of BBF length with $1 \%$ slope results in the lowest grain yield, $1496 \mathrm{~kg} \mathrm{ha}^{-1}$ (Table 2). On the other hand, for both 1 and 3\% slopes, higher grain yield, 2148 and 3318kg ha-1 exhibited, respectively by using $20 \mathrm{~m}$ length of BBF. The lower yield on the shortest BBF length might be related to the contribution of short BBF length for water loss through surface runoff, which reduces yield [15].

Further, on experimental plots having 2\% slope, $10 \mathrm{~m} \mathrm{BBF}$ length brought higher gain yield, $5757 \mathrm{~kg} \mathrm{ha}^{-1}$, which is preceded by the yield value of $5005 \mathrm{~kg} \mathrm{ha}^{-1}$ obtained by using $20 \mathrm{~m}$ BBF length. The result further revealed that for plots having slope of $2 \%$, wheat grain yield showed a consistent decreasing trend, from 5757 to $4211 \mathrm{~kg} \mathrm{ha}^{-1}$ as the length of BBF increases (Table 2). The superior grain yield obtained on the shortest BBF length over others could be related to the lesser SE recorded on the $10 \mathrm{~m} \mathrm{BBF}$ length related to the SE recorded on the 20 and $30 \mathrm{~m} \mathrm{BBF}$ length (Figure 2). In contrary to this study, the report of [16] reported an increasing trend of grain yield as BBF length increases.

Table 2: Interaction effect of broad beds and furrows length and slope on grain yield of wheat.

\begin{tabular}{|c|c|c|c|}
\hline \multirow{2}{*}{ Slope Gradient } & \multicolumn{3}{|c|}{ Broad Beds and Furrows Length } \\
\cline { 2 - 4 } & 10 & 20 & 30 \\
\hline $1 \%$ & $1496 \mathrm{f}$ & $2148 \mathrm{e}$ & $1652 \mathrm{ef}$ \\
\hline $2 \%$ & $5757 \mathrm{a}$ & $5006 \mathrm{ab}$ & $4211 \mathrm{c}$ \\
\hline $3 \%$ & $2923 \mathrm{~d}$ & $3318 \mathrm{~d}$ & $2933 \mathrm{~d}$ \\
\hline
\end{tabular}

Moreover, grain yield showed a trend toward an increase in BBF length. Grain yield has increased from 1496 to $2148 \mathrm{~kg} \mathrm{ha}^{-1}$ on the $1 \%$ slope land and from 2923 to $3318 \mathrm{~kg} \mathrm{ha}^{-1}$ on the $3 \%$ slope as the BBF length increased from 10 to $20 \mathrm{~m}$. Then it decreased to 1652 and $2933 \mathrm{~kg} \mathrm{ha}^{-1}$ at the longer slope length $(30 \mathrm{~m})$ for both 1 and $3 \%$ slopes, respectively (Table 2). However, the yield decreased from 2148 to $1652 \mathrm{~kg} \mathrm{ha}^{-1}$ and from 3310 to $2933 \mathrm{~kg} \mathrm{ha}^{-1}$ as the slope length increased from 20 to $30 \mathrm{~m}$ for both 1 and $3 \%$ slopes, respectively. Similarly, the study of [15] indicated a yield improvement as BBF length increases to some extent then the yield has turned to decline as BBF length further increases.

In general, grain yield of wheat showed an increasing trend with slope length, which could be related to the higher SDBF on the longer slopes (Figure 2). This also indicates that soil quality has increased on the longer slope length and as soil organic matter and nutrients on the soil surface transported from the upper to lower parts due to erosion [17].

\section{Conclusion}

This study showed that slope and BBF length and their interaction have a significant effect on yield and yield attributed of wheat, except for number of tillers. Superior yield was obtained from using combination of $2 \%$ slope with BBF length of $10 \mathrm{~m}$ followed by the yield resulted by using BBF of $20 \mathrm{~m}$ length. For both 1 and $3 \%$ slope fields, higher wheat yield was obtained on the $20 \mathrm{~m}$ length BBF. Deposition of the eroded soil showed an increasing trend with length of BBF and across the slope gradient, while wheat grain yield has increased as slope length increases, except for the $2 \%$ slope. However, there was no statistically significant difference among the tested slopes and BBF lengths on soil erosion and soil deposition, which might due to the fact that the selected slopes are categorized under normal and the same slope category. In general, this study has indicated the influence of BBF length and slope gradient on soil erosion and wheat production to some extent. This implies that combinations of BBF length and slope should be considered while draining the excess water on Vertisols, which needs further studies using different slope categories with more replications.

\section{Acknowledgment}

The authors acknowledge Ethiopian Institute of Agricultural Research for its support in all levels of this study. The authors 
greatly acknowledge Natural Resource Management Research team of Debrezeit Agricultural Research Center for their field and laboratory assistances.

\section{Funding}

This work was supported by Ethiopian Institute of Agricultural Research.

\section{Competing Interest}

Authors declare no competing interest

\section{References}

1. Pimentel D (2006) Soil erosion: A food and environmental threat. Environment, Development and Sustainability 8(1): 119-137.

2. Jutzi S (1988) Deep black clayey soils (Vertisols): Management options for the Ethiopian highlands. Mountain Research and Development 8(2/3): 153-156.

3. Hillel D (1998) Environmental soil physics: Fundamentals, applications, and environmental considerations. $\left(1^{\text {st }}\right.$ edn), Elsevier.

4. Pimentel D, Allen J, Beers A, Guinand L, Linder R, et al. (1987) World agriculture and soil erosion. Bio Science 37(4): 277-283.

5. Jijo T (2005) Land preparation methods and soil quality of a Vertisol area in the central highlands of Ethiopia. Universität Hohenheim (310); D-70593 Stuttgart, Germany, pp: 1-29.

6. Abdullahi A (2018) Erosion effect on soil physical properties in selected farmlands in Gidan Kwano, Niger State. Journal of Horticulture and Plant Research 2: 10-22.

7. El Swaify SA, Pathak P, Rego TJ, Singh S (1985) Soil management for optimized productivity under rainfed conditions in the semi-arid tropics. In: Stewart BA (Ed.), Advances in Soil Science, Springer-Verlag New York Inc, USA, pp: 1-64.
8. Nigatu A, Dirk H, Kahsay B, Moti J (2010) Irrigated vegetable promotion and expansion: the case of Ada'a Woreda, Oromia Region, Ethiopia.

9. Food and Agriculture Organization of the United Nations (FAO) (1980) A provisional methodology for soil degradation assessment.

10. Zhang Z, Sheng L, Yang J, Chen XA, Kong L, et al. (2015) Effects of land use and slope gradient on soil erosion in a red soil hilly watershed of southern China. Sustainability 7(10): 14309-14325.

11. Bagio B, Bertol I, Wolschick NH, Schneiders D, Santos MADND (2017) Water erosion in different slope lengths on bare soil. Revista Brasileira de Ciência do Solo, 41: e0160132.

12. Vliet VLJP, Hall JW (1995) Effects of planting direction of Brussels sprouts a previous cultivation on water erosion in southwestern British Columbia, Canada. Journal of Soil and Water Conservation 50(2): 188192.

13. Kramer LA, Meyer LD (1969) Small amounts of surface mulch reduce soil erosion and runoff velocity. Transactions of the ASAE 12(5): 638641.

14. Obaid ur R, Muhammad R, Rahina K, Sarosh A, Riaz H (2015) Slope gradient and vegetation cover effects on the runoff and sediment yield in hillslope agriculture. Turkish Journal of Agriculture-Food Science and Technology 3(6): 478-483.

15. Tesfaye Tefera, Kannan N, Hordof T (2016) Effect of furrow length and flow rate on irrigation performances and yield of maize. International Journal of Engineering Research and Technology (IJERT) 5(4).

16. Ruth Damtachew, Getahun Dereje, Negesse Gadissa (2019) Determining Appropriate Broad Bed Furrow Lengths on Vertisol of South West Showa, Oromia Region, Ethiopia. Desalegn T, Abera D, Indris S, Tolcha W and Hordofa T (Eds.), Proceedings of the Natural Resources Management Research completed Research activities Workshop. EIAR-HQ, Addis Ababa, Ethiopia.

17. Su ZA, Zhang JH, Nie XJ (2010) Effect of soil erosion on soil properties and crop yields on slopes in the Sichuan basin, China. Pedosphere 20(6): 736-746. 